AFRICAN

\title{
The rise of BRICS development finance institutions: A comprehensive look into the New Development Bank and the Contingency Reserve Arrangement
}

\author{
by Adrino Mazenda
}

School of Public Management and Administration

University of Pretoria

Ronney Ncwadi

Department of Economics

Nelson Mandela Metropolitan University

\begin{abstract}
At the fifth BRICS summit in 2013, the BRICS countries (Brazil-Russia-India-China -South Africa) agreed to form new multi-lateral development financial institutions such as the New Development Bank and the Contingent Reserve Arrangement. These new institutions are intended to perform similar roles to that of previously established international development institutions, particularly the World Bank and the International Monetary Fund while avoiding their biases towards lending to developing nations. This paper examines the role that these institutions play in changing the international financial architecture of development finance, particularly infrastructure development in the BRICS countries for the purposes of stimulating further trade and investment opportunities. It argues that the New Development Bank and Contingent Reserve Arrangement faces many challenges, such as issues of governance structures and decision making procedures which require integrity, transparency and political immunity in making lending decisions. It will also examine the role of China as a key partner and major source of capital in these development projects and, as well as its interests in strengthening its political and economic ties with other developing countries.
\end{abstract}




\section{Introduction}

The association of five major emerging national economies, namely; Brazil, Russia, India, China and South Africa (BRICS) has a special agenda towards assisting the Global South achieving its objectives of eradicating extreme poverty, reducing inequality and achieving sustainable development. Despite remarkable steps made in reducing poverty within India and China, BRICS countries still house nearly half of the world's poor and with the exception of Brazil have experienced a rise in inequality in recent years. The creation of the BRICS Development Bank or the New Development Bank (NDB) and the Contingent Reserve Arrangement (CRA) offers a real and concrete opportunity for meaningful reforms of the global development architecture, while ensuring that development financing is sensitive to the respective needs of BRICS countries such as their poorest and most marginalised communities (OXFAM, 2014).

The NDB and CRA are responses borne out of frustration with the developmental agendas and policies of existing international development institutions particularly the World Bank and the International Monetary Fund (IMF) (Cattaneo, Biziwick and Fryer, 2015). Prior to the establishment of the NDB and CRA, BRICS countries have individually devised ways to subvert from the bias of the Bretton Woods institutions in particular the IMF and World Bank. For example, India, a signatory in the Bretton Woods agreement in 1944, balanced its development objectives by partnering with the Bretton Woods institutions while pursuing its own developmental trajectories locally such as through the nationalisation of the Indian National Reserve Bank in 1947 (Singh and Mukamba, 2015). Similarly, China took on a similar approach with the 1994 formation of the Chinese Development Bank (CDB) and the 2014 Silk Road Fund that supported various initiatives on structural and socio-economic development in Africa, Latin America, Asia and Europe. Other initiatives included an earlier prototype of a Global South centric development bank, namely the 1959 Inter 


\section{AFRICAN \\ EAST-ASIAN \\ AFFAIRS \\ THE CHINA MONITOR}

-American Development Bank (IDB) but it was largely unsuccessful given its funding limitations at the time.

Although the NDB and CRA has given rise to structural changes in international development aid governance, there exist deep concerns about the operations of these institutions in BRICS countries regarding their ability to push towards inclusive and sustainable growth. Einchengreen (2014) in Cattaneo et al. (2015), criticised the conflicting aims of the CRA such as its ability to balance incompatible interests of borrowers and lenders during financial crises. Also, other observers have questioned the NDB's capacity to finance small and medium enterprises (SMEs).

Against this background, this paper explores the NDB and the CRA contribution to international development financial institutions' reform. It addresses the necessity of the NDB and CRA in supplementing financial proceeds from various BRICS' national development banks. As such, the present structure and operations of the NDB and the CRA alongside existing regional and international financial institutions in pursuit of the BRICS' economies development agenda is explored. The first section reviews literature from Latin America and India towards development finance institutionalisation of the BRICS. The second section discusses the BRICS national development banks in their individual capacities. Following is a discussion on the structure, operations and limitations of the NDB and CRA. Conclusions and policy recommendations are offered in the last section.

\section{Literature Review}

This section provides specific background literature on development financial institutions in Latin America and India that pave way for the proposal and development of the NDB and the CRA. The Latin American countries as well as India are chosen due to their active role in shaping the global financial systems in their relevant economies. The Latin American region has a variety of regional, monetary and financial institutions operational since the beginning of the $20^{\text {th }}$ century without notable failures (Avalle, 2013). On the other hand India was a signatory to the Bretton Woods which paved way for the establishment of the IMF and, therefore, its experiences are relevant for evaluating and understanding the 
shortcomings of the IMF and the World Bank. While Russia, South Africa and China's experiences are also of interest, this paper will not address them given their more recent evolution within the international developmental landscape.

\section{Case of Latin America}

In an effort to reform the international financial architecture, particularly systems of the IMF, various regional, monetary and financial cooperation initiatives have taken centre stage since 2000. In the Latin American countries, regional economic integration enables implementation of sound macro-economic policies and prudential financial standards to cushion against financial fragility. This has led to the establishment of the Multi-lateral Development Banks (MDB) in Latin America. The core competency of the MDBs is to lend money to governments in developing countries and economies in transition. These funds, in turn, can be used to cover shortfalls in budgets or to allow governments to continue program development without having to increase their debts by borrowing from the international capital markets. As a result of providing this financial assistance, MDBs introduce their own policy agendas into the governments to which they lend money (Avalle, 2013). The policy instruments utilised under the Structural Adjustment Programs (SAPs) in Peru, Argentina and Bolivia from the 1980s through the 1990s reduced the ability of the states to provide adequate social insurance and safety nets as government budgets were cut drastically and the role of the state receded from the market (McCutchan, 2010). One prominent example of an MDB is the IDB that was established in 1959. The IDB's goal is to facilitate economic and social development in Latin America and the Caribbean and has financed projects worth over US\$263 million to various Latin American countries. From 1961 to 2000 annual lending grew dramatically from US\$ 264 million to US\$ 5 billion. Despite its desires to finance more projects, the IDB's ratio of approved loans is extremely low compared to that of the World Bank and the Andean Development Corporation (CAF) (Avalle, 2013).

The MDBs partner with other regional, monetary and financial institutions to support the work of infrastructure development and other government development projects (Sampaio, 2015). These institutions operate on three levels. Grants of long term 


\section{AFRICAN \\ EAST-ASIAN \\ AFFAIRS \\ THE CHINA MONITOR}

credit are classified in the first level. The second level deals with short-term external financing. In this level issues of balance of payment constraints and currency mismatches are dealt with. Moreover, bond payments, repurchase and loan approvals are facilitated. The third level engages the exchange rate system and issues of further monetary integration, an issue Latin American countries still struggle with (Sampaio, 2015). Much work has been done in Latin America on the first two levels. Regional financial institutions comprising of the Reserve Fund of Latin America (LARF), the Local Currency Payment System (LCPS) and the Reciprocity Payment and Credit Agreement (RPCA) address issues of balance of payments. Latin American countries also gain access to long term credit through the Structural Convergence fund of MERCOSUR, the River Plate Basin development fund, the Latin American bank of Foreign Trade and the Brazilian national development bank (Sampaio, 2015).

As Seatzu (2014) observes, Latin American regional multi-lateral organisations play a rapidly increasing role in the supply of development finance and technical assistance to the countries of the Latin American (LAC) region. Firstly, reserve pooling through the Andean Reserve Fund established in 1976, sub-regional multilateral organisations and international sub-regional banks help countries of the region to mobilise financial resources for productive activities. Second, sub-regional multi-lateral development organisations help the LAC countries to increase their role and level of integration in international capital and financial markets while also strengthening their internal capital markets. For example, they have improved their funding conditions and are now able to issue bonds in Latin American currencies. Together with global multi-lateral financial institutions, international sub-regional development banks support the Latin American countries to guard against financial fragility though liquidity support. Wealthier countries in the group, such as Brazil and Mexico continually allocate resources to these organisations as does China in the NDB and CRA perspective. These multi-lateral organisations of the LAC provide a positive platform and modelling framework in the NDB and CRA establishment. Despite the achievements of these organisations, they are not given due legal recognition within the international multilateral financial system. 


\section{Case of India}

As Chandrasekhar observes (2014), India's development cooperation (IDC) from 1950 to 1980 was strongly motivated by ideology and political calculations. The IDC utilises the Indian Development Assistance as a foreign and economic policy tool to accelerate India's economic and political boom through South-South cooperation (Jobelius, 2007). IDC was founded on the main principles of sustainable and inclusive growth, non-conditionality, mutual gains, demand-driven support and the sharing of India's domestic development appearance (Singh and Mukamba, 2015). From 1990, India transitioned from a mixed-state economy towards a market-oriented economic approach. Its foreign policy became increasingly influenced by geo-economic and international political conditions; as such, India vicariously participated in a number of development forums such as the United Nations (UN), the World Trade Organisation (WTO), the World Bank and the IMF, prompting the development of other multi-lateral development institutions (Singh and Mukamba, 2015).

India has substantial experience in the operation and functioning of existing development institutions and multi-lateral institutions. In 1944, India was amongst the 44 signatories to the Bretton Wood agreement that paved way for the formation of the IMF. India was a founding member of the International Finance Corporation formed in 1956 and the International Development Association initiated in 1960. India's relationship with these international institutions was based on the North-South corporation prism, a situation where India requested financial and non-financial resources with very minimal costs (Singh and Mukamba, 2015).

Presently, India has changed its positioning towards multi-lateral and regional development institutions from that of a borrower to that of a lender. Unlike some of its BRICS counterparts, India's national development finance is managed by development financial institutions (DFIs), which came about after nationalisation of the Reserve Bank of India in 1947. The DFIs are meant to finance the country's infrastructural needs and reduce the developmental gap that separated India from developed economies. In 2015, there were more than ten national DFIs that performed regulatory, supervisory and financing roles within their sectors (Singh and Mukamba, 2015). 


\section{AFRICAN \\ EAST-ASIAN \\ AFFAIRS

There has been a significant increase in domestic infrastructure spending by India's DFIs from 1990 to 2012. While achieving success in meeting several infrastructural needs, India still requires over US\$ 1 trillion in infrastructural investment to fill in its infrastructural deficit. India's DFIs, the NDB, CRA, as well as regional and multilateral institutions as envisaged in the World Bank strategy of inclusive growth and poverty reduction, are crucial in bridging the developmental gap (Singh and Mukamba, 2015).

\section{National Banks in BRICS member countries}

To grasp an insight on effects of the NDB and CRA towards infrastructure development and financial assistance of the BRICS economies, one cannot neglect the role of the BRICS national banks, especially their role in export and foreign direct investment promotion. This section will analyse the operations of the BRICS national banks in meeting infrastructural needs and other financial assistance for the BRICS member countries. The Brazilian National Development Bank, the Russian National Development Bank, India's Export-Import Bank, China's Development Bank and the Southern African Development Bank will be discussed.

\section{Brazilian National Development Bank (BNDES)}

The BNDES was formed to integrate Brazil together with the Latin American countries. This mandate is achieved through the provision of long-term credit for financing investment projects, acquisition of equipment and assistance towards trade in goods and services. The Finamex, an export financing line was formed by the BNDES in 1990 to promote the export of goods and services. The program became BNDES-export-import in 1997 and performs a similar role to export credit agencies in the provision of long-term financing to high-tech industries and small and emerging enterprises. From 2003 onwards, Brazil became more concerned with SouthSouth and sub-regional collaborations. Through the South American Nations initiative of $2008,{ }^{1}$ the BNDES became committed on funding regional projects (Sampaio, 2015). The BNDES-exim provides credit shipment lines to local producers, foreign companies and other financial entities. In 2013, credit shipment lines to foreign entities accounted for 35 per cent of the US\$ 7.1 billion allocated to general export 
financing (Sampaio, 2015). In 2013, the BNDES grants were focussed mainly in financing exports to Latin America. Over 57 per cent of loans were destined towards the region as compared to 34 per cent in 2009. Venezuela had the largest share of 41.2 per cent, followed by Cuba (18.3 per cent), Peru (13.9 per cent), Argentina (10.9 per cent) and Ecuador (5.4 per cent) (Sampaio, 2015).

The BNDES success lies in the intensity of grants to finance exports to the Latin American countries as shown in the rising shares directed towards Cuba and Venezuela, and a decline in disbursements for exports to the United States (US) (Sampaio, 2015). The expansion of the BNDES' grants to the Latin American countries was mostly due to market forces than the desire of the regional nations to integrate. The bank is also responsible for funding overseas projects. Examples of recently funded projects in 2014 include a port in Cuba worth US\$ 957 million and an airport in Mozambique worth US\$ 200 million (Leahy, 2015). The beneficiaries of BNDES grants are mostly economies with strong trade ties with Brazil. This is exactly the opposite of the theory on 'regional banks functions' which postulates that development finance should flow from developed to developing countries (Sampaio, 2015). The functions of the BNDES are market-oriented due to their response in funding Brazilian exports and Brazilian entities interested in establishing new business ventures within the region (Sampaio, 2015).

While the BNDES provides practical lessons for the establishment of the NDB, critics such as Mansueto Almeida ${ }^{2}$ and Vinicius Carrasco ${ }^{3}$ have questioned the sustainability of the BNDES projects. In some situations, the funded projects fail to protect indigenous rights or facilitate information asymmetry for active participation by all involved stakeholders. To some extent, some projects have negative environmental and social impacts and commercial benefits that override structural change and technological progress (Leahy, 2015). Possible solutions regarding project sustainability issues raised above include eliminating information asymmetry through education, focus groups as well as integration into global value chains. This helps to ensure that environment and societal welfare are not compromised by the developmental projects (Sampaio, 2015). Moreover, the BNDES should give preference to short-term loans at an affordable rate. Finally, democratic governance should be applied to- 


\section{AFRICAN \\ EAST-ASIAN \\ AFFAIRS \\ THE CHINA MONITOR}

wards regional integration in order to avoid the process being oriented towards a single country's foreign policy (Sampaio, 2015).

\section{Russia's Development and Foreign Affairs Bank-Vnesheconombank (VEB)}

The main function of the VEB is to promote the competitiveness of the Russian economy. This is achieved through the stimulation of economic activity towards infrastructure development, technological innovation, special economic zones, environmental protection, exports support and SMEs development (SELA, 2015). VED also funds foreign investment projects together with the World Bank and other banks in Europe, such as the Investment bank of Europe to fund overseas projects (VEB, 2015a). The bank oversees the implementation of investment projects as well as export promotion through provision of export credits, leasing transactions, insurance and securities and guarantees amongst other offers (SELA, 2015).

Funding for VEB activities is obtained from the Federal Budget, the National Wealth Fund and the Central Bank. Moreover, these activities are governed by the Federal Law on Bank for Development (Act 82-F7 of 2007) (SELA, 2015: 19). The guidelines followed in investment project selection are mostly based on compliance with the bank's standards. The maximum repayment period for projects of more than US\$ 305 million is five years. The minimum accepted share contribution is US\$ 152.5 million (SELA, 2015).

Since 2007, the VEB has provided financing for long-term capital-intensive projects. These projects could not be financed by private commercial banks due to their complex requirements and the incapacities of the private commercial banks to provide sufficient capital. In executing its mandate, the VEB heeded environmental concerns while avoiding unprofitable operations and gave preference to public-private partnerships (VEB, 2015b: 5). From 2010 to 2014 VEB increased support for Russian industrial exports by more than 80 per cent, which is equivalent to 22.7 billion rubles (US\$ 409 million). Guarantees during the same period increased by more than 100 per cent and reached 99.58 billion rubles (US\$ 1.53 billion) (VEB, 2014: 46).

The VEB provides extensive export support to the Independent States of the Commonwealth (CIS countries) Eastern Europe, Asia, Latin America as well as African 
states. The export support is concentrated in aircraft manufacturing, nuclear enhanced projects, high-tech exports as well as construction of transport machinery (VEB, 2014: 46). Overall, the VEB has been successful in acquiring assets and funding investment projects abroad in the form of direct investment, hence, making the Russian economy competitive (VEB, 2015a). While the VEB involves funding from private investors, at least 90 per cent of VEB projects are funded from the bank's balances, with most of liabilities in the form of reserve bank deposits. The Russian Central Bank provides both capital and subsidies that are used to finance projects of other entities that the VEB could not meet. In 2013 the Russian government disbursed subsidies worth 76 billion rubbles (US\$ 1.35 billion) (Morozkina, 2015).

A possible role for the NDB to complement VEB's work is to provide investment capital and consultancy to the Russian Central Bank and other development entities. Additionally, the NDB can provide assistance to other governmental entities that deal with sectors that are relatively neglected such as Russian's lagging transport sector (Morozkina, 2015). Moreover, the NDB should collaborate with the Russian public-private sector partnership through joint ventures on developmental projects. The success of the Pulkovo airport project is a good exemplar of such possible partnerships. The Pulkovo airport project is a public-private partnership between the Russian government and the private sector carried out by the Northern Capital Gateway LLC Company (NCG) in 2010. The project involved modernisation of existing airport terminals and construction of new terminal, north boarding gallery and concomitant infrastructure (Morozkina, 2015). The government has ceded operations of the airport to the NCG company through pooling of funds. Of the total project funding, NCG contributed an initial equity capital amounting to almost US\$ 460 million. IFC, together with the European Bank for Reconstruction and Development (EBRD), contributed US\$ 223 million and the VEB, a government owned bank, contributed US\$ 837 million. The NCG comprises of VTB capital, Fraport AG, Koltseva holdings LTD and Horizons Air Investments SA, with equity stakes of 50 per cent, 35.5 per cent, 7.5 per cent and 7 per cent respectively (Morozkina, 2015). 


\section{AFRICAN \\ EAST-ASIAN \\ AFFAIRS

\section{The Indian Export -Import Bank (EXIMINDIA)}

EXIMINDIA is a government-owned entity tasked with aligning the country's foreign trade and direct investments with growth. More specifically, the bank positions India as a manufacturing hub for value added exports and job creation (SELA, 2015: 19). Funding of the bank projects is mostly related to export credit services and guarantees. However, the bank also funds acquisition of capital equipment, and is involved in project consultancy. Between 2014 and 2015, the bank approved loans of US\$ 10.6 billion under various lending arrangements (EXMINDIA, 2015: 15).

The Bank also stands to support direct outward foreign investment through the Indian Project Exporters in the form of funded support and project-related guarantee facilities (EXIMIDIA, 2015:20). Examples of projects supported by EXIMINDIA in 2014 included the construction of a Petroleum refinery plant in Nigeria, the Qatar electricity supply system, and the Saudi Arabia airport construction (EXIMINDIA, 2015: 19).

In addition, the Bank extends credit to foreign entities and development banks. The credit is channelled towards infrastructural equipment imports. In 2014 there were 194 lines of credit commitments valued at US\$ 11.7 billion ready for implementation in 63 countries (EXIMINDIA, 2015: 21). In 2015, 17 lines of credit were granted to 13 African states and Cuba, Vietnam and the Fiji Islands amongst non-African states. They were meant to support electrification projects, rice self-sufficiency programs, fertilizer and cement plant establishments and the upgrading of the sugar refinery industry (EXIMIDIA, 2015: 21). Finally, the Exim Bank acts as a guarantee for local companies in securing credit from international financial institutions. Moreover, the bank facilitates seminars with multilateral organisations for linking business opportunities (EXMINDIA, 2015: 30).

Similar to other IDFs, the Exim Bank has emerged as a strong advocate in promoting trade and investment. The work of the bank is praised as it does not sponsor development projects only in India, but also in other developing nations from Africa and the Middle East. Nevertheless, India still needs to boost an infrastructural gap worth billions of dollars (EXMINDIA, 2015: 31). The NDB and CRA will increase the 
financial base of EXIMINDIA against stringent lending arrangements from private entities.

\section{China Development Bank (CDB)}

The CDB is a state-owned entity with a mandate to provide medium and long-term loans for industry and infrastructure development. The sector also supports development of basic industry and other growing sectors. The CDB also funds grassroots investments and businesses and is involved in the provision of healthcare and education. Finally, the CDB promotes China's outward investments and international business partnerships (CDB, 2015a: 58). In addition, the CDB has established an international network of 707 overseas banks in 106 world markets. The offshore banks serve the purpose of internationalising the Chinese currency as well as improving the banks service capability (CDB, 2015b: 57).

On outward investments and international business partnerships, the CDB has engaged in major cross-border investment in Africa, Asia and the Latin American countries. The acquisition of Peru's La Bambas copper mine for US\$ 7.2 billion by Minmetals represent the largest cross-border acquisition by China until 2015 (SELA, 2015). The Bank also supported the construction of US\$ 473 million coal power plant in Indonesia and US\$ 45 million First Automobile Works (FAW) car assembly plant in South Africa (CDB, 2015b: 58). Finally, the CDB contributes to the formation of the Silk Road Fund through funding from the China-ASEAN bank and the Shanghai Interbank. The Silk Road Fund emanates from the New Silk Road Strategy, which aims at supporting major projects in Eurasian countries, including nuclear related companies and major foreign railway line investments (CDB, 2015b: 57).

The CDB has strengthened its position in international cooperation through supporting various initiatives in structural and socio-economic development projects in Africa, Latin America, Europe and Asia. The principles and objectives of the NDB are partly mirrored in the mandate of the CDB. Through its activities, the CDB had forex loans worth over US\$ 200 billion in 2014, and off-shore balances of US\$ 8.6 billion giving basis for establishment of the CRA which is a capital balance to cushion against liquidity pressures (SELA, 2015: 22). 


\section{AFRICAN \\ EAST-ASIAN \\ AFFAIRS

\section{The Southern Africa Development Bank (DBSA)}

The South African based DBSA was formed with the objective of promoting sustainable development in the socio-economic sectors of agriculture and industry among others. This is made possible through financial and other investment support from the Program for Infrastructural Development in Africa (PIDA), the New Economic Partnership for Africa Development (NEPAD) and the Industrial Development Cooperation (IDC) (DBSA, 2015a: 13).

The primary purpose of DBSA is that of promoting sustainable economic development, institutional capacity building and human resources within the SADC region. By August 2015, DBSA regional project support on investment shortfalls covered all 15 SADC member states and most African nations (Qobo and Soko, 2015). In 2013, the DBSA also expanded its disbursement scope to provide access to infrastructure development solutions across the Southern African Development Committee (SADC) and Sub-Saharan African states (DBSA, 2015b: 41).

In fulfilling its mandate for international financing, the Bank disbursed more than US\$ 300 million in financial products services and products to the region as well as partners in the public and private sectors during the 2013/2014 fiscal year. Total approvals were US\$ 345 million in the same year with a lion's share of investment going towards the energy sector of the Democratic Republic of Congo (DRC), Ghana and Zambia (DBSA, 2015b: 41). Regionally, infrastructure investment for roads construction accounted for the majority of shares at 43 per cent in 2013/2014 followed by the energy sector ( 21 per cent), the transport sector (19.1 per cent), communications sector (9.3 per cent) and the infrastructure fund comprising of 8.4 per cent (DBSA, 2015b: 42).

Therefore, we can attest that the DBSA is a strong mechanism through regional integration of the African continent. However, these efforts by the DBSA still fall short of meeting the significant infrastructure development demand within the region. In this regard, loans from the NDB will help expand the scope of DBSA disbursements in line with its objectives of broadening their product offering as well as targeting 
the expertise of other regional banks and lobbying to co-finance infrastructural projects (DBSA, 2015b: 44).

\section{The Structure and Operations of the BRICS New Development Bank}

The NDB has a mandate to provide interest free loans to developing countries principally for sustainable infrastructural development projects in the BRICS economies (BRICS, 2013a, 2015). The main function of the NDB is to utilise resources in support of infrastructural investments in priority projects. This comes in the form of equity participation, guarantees and cheap loans that are approved using a transparent governance system. The initial start-up capital is US\$ 100 billion for all members (BRICS, 2013b). The bank operates within internationally stipulated legal guidelines for all financial institutions. These obligations ensure prudential financial contact and operation as with any other development institutions. Finally, the NDB offers technical assistance in implementing priority projects as well as administration of special funds to support the projects (BRICS, 2014a: paragraph 8).

All the members of NDB have equal voting power, with no provision for a veto. Every country's contribution is consensually determined by the majority (BRICS, 2014b: paragraph 8). However, there is some uncertainty as to membership criteria since any membership expansion must not reduce the BRICS' capital share of 55 per cent so as to not lessen the power of the BRICS member states. The threshold is calculated from the US\$ 100 billion initial capital contribution (Dixon, 2015). For the first five years of operation (2014-2018) the NDB headquarters are located in Shanghai, China. The elected President is from India. The chairmanship is held by Russia and Brazil with special classifications of board of governors and board of directors respectively. Finally, South Africa was chosen as the first regional centre. Rotations will follow in all areas within the stipulated time of five years (BRICS, 2014b: paragraph 12).

\section{Institutional Design of the NDB}

According to Zhu (2015), from a South-South cooperation perspective amongst the BRICS countries (financial support amongst developing countries), five principles 


\section{AFRICAN \\ EAST-ASIAN \\ AFFAIRS

have been prioritised in the NDB mechanism design. The principles are fair governance, market based operation, non-interventionist approach, localisation and constructive supplement. The setup for equal funding responsibilities and discourse power amongst the BRICS demonstrates commitment to substantial international innovative reforms by the BRICS countries.

The NDB shows the principle of fairness in its innovative governance structure. Its stock rights are equally distributed amongst the BRICS membership. This means stock rights are not divided according to the BRICS countries gross domestic product (GDP) in global GDP. A market-based operation model enables the bank to diversify sources of capital by including capital drawn from the market and other channels other than from the BRICS governments. It also enables the introduction of governance structures used in modern companies, and market-based recruitment strategies to attract the best international talent ( $\mathrm{Zhu}, 2015)$. The non-interventionist approach insists on respecting the rights of BRICS member countries on the choice of their own policy space and development paths. It also safeguards against clauses that allow for intervention in existing BRICS multilateral development banks, which have a negative bearing on the operational efficiency of the NDB (Zhu, 2015). The non-interventionist approach also applies to any country that borrows from the NDB (Zhu, 2015). The localisation principle also involves equal communication and mutual learning through various organisations amongst member states. The Human Sciences Research Council (HSRC) in South Africa has been given a mandate for sharing and communicating experiences across BRICS countries with the aim of achieving organic synthesis of funds and wisdom gathering. Finally, the constructive supplement principle entails cooperation between the existing multilateral financial institutions and the NDB. The spectrum of cooperation here ranges from adopting congruent prudential financial standards to constructive participation in co-financing critical and specific infrastructural projects.

\section{Governance of the NDB and its effect on Established Financial Institutions}

The NDB has been seen as a global alternative to the World Bank Group as an institution primarily controlled by emerging economies (Reisen, 2013). Experiences from 
each of the BRICS countries show that the NDB's provision of development finance can be free from any conditionality. For developing nations discontented with the interventionist approaches of international multi-lateral institutions and regional development banks, growth in South-South cooperation is a welcomed counterbalance to the existing situation (Reisen, 2013). Nevertheless, the absence of coherent alternative development funding initiatives from BRICS' and inadequate resource funding of the NDB may lead to projects negative with environmental, social and economic impacts posing a challenge to the sustainability of potential infrastructure (Schablitzki, 2014).

\section{The NDB and South-South Cooperation}

There has been a decline in support from developed countries and multi-lateral development banks in financing various projects of developing countries (North-South cooperation) (Zhu, 2015). Under these circumstances, the rise of emerging economies and the new international economic system through South-South cooperation (financial support amongst developing countries) forms an important element of the BRICS' cooperation agenda (Zhu, 2015). South-South cooperation focuses on respect, reciprocal treatment, mutual gains, maximum results and joint development as compared to the existing inequalities in the North-South economic relations. Through South-South cooperation, the economic status of developing countries can be uplifted, meaning that they can receive financial, technological, managerial, marketing and other developmental support through a new international economic system based on investment, trade, finance and industrial transfers between emerging economies (Zhu, 2015).

The strategic role of the NDB is to facilitate new financing sources separate from developed nations. It also ushers in new financing fields in infrastructure development, as compared to existing multi-lateral institutions and regional development banks which are largely devoted to multi-lateral development projects with less bearing on infrastructure development. The major projects funded include poverty alleviation and alternative energy methods such as gas and biomass (Driscoll, 1996). The stringent lending conditions emanating from the North-South cooperation contributes 


\section{AFRICAN \\ EAST-ASIAN \\ AFFAIRS

to the politicisation and bureaucratisation of the multi-lateral institutions. SouthSouth cooperation with advent of the NDB prompts a more equal and balanced development partnership amongst developing nations. Reduction in loan costs and lending conditions leads to a sound customer-oriented development finance service (Zhu, 2015).

According to Qobo and Soko (2015), the NDB catalyses structural transformation on the African continent, as well as stimulate regional integration through financing infrastructure projects. The NDB complements efforts by the DBSA and the IDC in leveraging support of BRICS projects. Funding provided by the IDC is in the form of loans, equity and quasi equity. From 2001 to 2010, IDC had funded more than 50 projects in over 15 African states approving loans to the sum total of US $\$ 1.98$ billion (Qobo and Soko, 2015).

China and South Africa are the major trade and investment partners of Africa. Their membership in NDB processes and operations means that there is a high likelihood of African countries benefiting from major cross-border investments with proceedings from the NDB disbursements. Moreover, through South-South cooperation Africa will get preferential treatment in loan disbursements to develop its marginalised infrastructure. This will ease the burden on the African Development Bank (ADB), the DBSA and the IDC which are inadequately funded. China is especially uniquely positioned amongst large emerging markets capable of funding significant development finance initiatives like the NDB, with foreign exchange reserves estimated at US\$ 3.8 trillion in December 2014 (Biswas, 2015). Recognising that such initiatives will strengthen its political and economic ties with other developing nations, China, thus, exercise more significant leadership in global development finance (Biswas, 2015).

\section{The Structure and Operations of the Contingent Reserve Arrangement}

The CRA protects against short-term balance of payments problems and provides equal support for the stabilisation of the BRICS countries' financial sector (BRICS, 2014c: article 1). The BRICS countries made an initial contribution of US\$ 100 billion towards the CRA establishment. China contributed the largest share of about 
US\$ 40 billion, while Brazil, Russia and India contributed equal proportions of US\$ 18 billion respectively. South Africa's contribution was the lowest at US\$ 5 billion (Cattaneo et al., 2015). The participating countries are entitled to own resources committed by them to the CRA unless a member request assistance via a currency swap (BRICS, 2014c: article 2). The maximum access limits to the fund and how much each member country is allowed to borrow is determined by each country's relevant multipliers. This multiplier is determined by each country's capacity to generate income (BRICS, 2014c: article 5). China's multiplier of 0.5 implies that it can only borrow half of its total contribution, while Brazil, Russia and India are allowed to borrow the full sum of its contribution with a multiplier of one and South Africa can request twice its commitment with a multiplier of two. Approval of other members is required for amounts greater than 30 per cent of the reserve (BRICS, 2014c: article 5).

CRA instruments' comprises of liquidity tools and precautionary tools. Both tools are meant to cover short-term balance of payment requirements but with different degrees of response (2014c: article 4). The CRA provides for currency swaps operations when one party requests bailout support. Rates are based on the US dollar with reference to the spot market rate for repurchase calculations. Interest is paid based on the sum total requested by a member and is denominated in USD, rather than the value of the member's currency. The maturity date for repurchase is six-months for un-linked drawings and at least 12 months for IMF linked drawings. Liquid drawings maybe renewed thrice on un-linked drawings and twice on drawings related to the IMF. Precautionary related drawings are non-renewable (BRICS, 2014c: article 12).

The rules and guidelines stipulated in the CRA treaty govern every member. The stipulations include compliance with the banking surveillance system and information disclosure as highlighted in the IMF treaty, as well as proscription of all accruals with other financial institutions for magnified lending (Cattaneo et al., 2015). CRA governance consists of the standing committee and the governing council. The governing council is highest in command and comprises of member representatives from the central bank governance. The council stipulates the adjustments in interest rates, prerequisites and conditions, drawings maturity period and changes to access 


\section{AFRICAN \\ EAST-ASIAN \\ AFFAIRS

limits and multipliers. The council is also allowed to change the scope of the CRA instruments and administer a strong surveillance system (Cattaneo et al., 2015). The Standing Committee which is second in governance level has a mandate to decide on requests by the participating parties. The composition of its officials is made up of representatives from each country's Central Banks. A weighted voting system is used for decision making in support requests. Other important decisions are made by consensus. In all levels of decision making of the standing committee, five per cent of the voting right is distributed equally among the participating countries, while the remaining 95 per cent depends on the committed value to CRA by each participating country.

\section{Lessons for the CRA Operations}

The CRA has been commended on the way it embraces the liberal ideals espoused by the main multi-lateral processes, the ideals of free trade, financial development and financial globalisation. Critics accept the liberal ideas, but argue that the multilateral process has been abused by the traditional multi-lateral institutions such that the CRA in its present condition is unlikely to correct (Cattaneo et al., 2015). Unless reforms on expansion and IMF de-linking amongst others are undertaken, the CRA is likely to be ineffective. As Cattaneo et al., (2015) argues, the work of the CRA in its present condition resembles similar agreements made by the ASEAN +3 grouping from the year 2000 to 2010, however ineffective during the 2008 crisis. Membership size, IMF linking and lack of rapid response to balance of payments' difficulties were major problems which affected the Chiang Mai Initiative (CMI). For example, the drawing rights of South Africa to the equivalent of US\$ 10 billion and at least US\$ 2.8 billion unlinked to the IMF is inadequate to meet major balance of payment problems (Cattaneo et al., 2015). Thailand, an economy whose growth was then equivalent to 40 per cent of the present South Africa's growth, experienced the same situation in 1997, when it requested about US\$ 17 billion from IMF. The IMF linking has to be supplemented through a process of counterweighting. While counterweighting is presently possible, it is highly unlikely that nations would consent to the IMF conditionality due to disputes about voting shares, and resentment from past experiences (Cattaneo et al., 2015). In light of these criticisms, the CRA has drawn 
positive lessons from ASEAN +3 processes with regard to its institutional design, scope and operations so as to subvert potential problems that other institutions have faced.

\section{Conclusions and Recommendations}

The establishment of BRICS development finance institutions provides an important platform for the advancement of the global financial systems reform. These reforms can bring about positive benefits to the developing countries misrepresented in existing multi-lateral institutions' development issues.

The NDB can be a valuable tool for the implementation of regional and global strategies for sustainable development. However, the NDB might face challenges in the short run. For example, decisions regarding capital structure and governance arrangements may have unintended repercussions that could initially restrict the NDB's scale and effectiveness. The BRICS economies have pledged the provision of at least US\$ 150 billion for each partner in the short term, and raising another US\$50 billion over the next six years (Humphrey, 2014). This is a difficult task as most of the BRICS economies are mired in cash constraints arising from various local political and economic problems further agitated by a drastically overstated dollar dominance which can only be addressed if exchange is transacted in local currencies. Projections as reflected in Humfrey (2014) show a likely loan portfolio in the US\$ 40-65 billion range after ten years of operation, which is fairly modest in relation to existing MDBs.

Even though the BRICS as a group are contributing to global growth, sovereign-debt downgrades for some of its member states could result in higher borrowing costs in international markets. Slow growth makes lending to risky infrastructure projects risky. The expected bond rating of the NDB will also most probably restrict its financial flexibility and limit demand for its services for some emerging economies due to potentially high loan costs. Finally, lack of clear leadership as exercised by the founding members on an equal shareholding may hinder expansion and flexibility.

In April 2016, the NDB made progress by issuing the first round of loans to the 


\section{AFRICAN \\ EAST-ASIAN \\ AFFAIRS \\ THE CHINA MONITOR}

BRICS nations for green energy worth US\$ 811 million. Additionally, the Bank planned a five year interbank bond in Chinese Yuan worth US\$ 6.1 trillion, a reflection of Beijing's growing importance to global financial strategic processes. The bond is expected to be launched in the second quarter of 2016. Nevertheless, this also introduces much uncertainty regarding future NDB bond issues. Chinese US\$ 6.1 trillion interbank bond market represent the bank's only viable debt-market funding option at the present moment and China's domestic currency policies regarding the Chinese bond market may affect plans to serve the broader membership. Uncertainties are also present regarding the rate of currency swaps between the Yuan and other BRICS currencies especially after recent downgrade in the Yuan's value. Having said that, the market based rate for currency swaps between the NDB member countries is always a solution to balance of payments and exchange problems between the member countries. Other future areas for NDB development include how the BRICS joined forces on IMF quota formula reform and as well as BRICS finance ministers holding discussions on launch of a bank institute ratings agency..

The recently launched AIIB (Asian Infrastructure Investment Bank) poses a challenge to the NDB given its contrasting governance principles as well as the intensity of Chinese efforts and vigorous leadership in setting an interim secretariat, appointing new staff and intensive lobbying to persuade other countries to join. China being a main player in both institutions could expose the attention given to NDB in the event China face hiccups in her economy in the long run. Presently the work of the NDB and AIIB is not contradictory. Both institutions are involved in the business of infrastructure development and the provision of loans. China has put in effort to assure its member partners that while it may be a Beijing-led initiative, it is not Beijing -owned or controlled. Additionally, its focus for now is heavily Asia-centric, which means the work of the NDB is mostly Africa and Latin America centric.

The NDB will, however, remain influential due to the presence of the CRA function. There are some challenges in some functions of the CRA which need be addressed. The primary emphasis on finding ways to cushion against balance of payment pressure and eliminate the IMF-linked drawings and requirements is difficult to achieve. A transparent surveillance system, research facility and modalities for a rapid crisis response should be developed to bypass competition from existing international fi- 

AFFAIRS

nancial institutions while eliminating possibilities of failure in the long run. Finally, the criteria for CRA membership should be revised to make them more inclusive and expansive.

\section{Endnotes}

1. The CDB, through the Africa Development Bank, approved the creation of a US\$ 5 billion China-Africa Development Fund in 2007. The investment of the funds was targeted at providing capital for Chinese enterprises engaged in development, investment, economic and trade activities in Africa. The fund was also meant to provide support for African countries' agricultural, manufacturing and energy sectors, as well as support for urban infrastructure and the extractive industries. More so, a US\$ 20 billion package was released by China Exim Bank towards Africa's infrastructure refurbishment over three years (Corkin et al., 2008). Taking into account these experiences, the NDB and CRA has adopted positive features from Chinese CDB as well as Latin American financial institutions. Features learnt and implemented include systems on lending, offerings of short-term external finance, as well as balance of payments management to protect against short term liquidity problems (Sampaio, 2015).

2. Mansueto Almeida, is an analyst at Brazil's Institute of Applied Economic research.

3. Vinicius Carrasco, is a Stanford-educated economist at the Pontifical Catholic University in Rio de Janeiro. 
AFRICAN

EAST-ASIAN

AFFAIRS

\section{Bibliography}

Anderson, J. E. 2005. Economic integration and civilizing commerce hypothesis, Working Paper 673. [Online]. Available: https://www2.bc.edu/ anderson/ PredEnfChoice.pdf. [Accessed: 29 May 2016].

Avalle, O. A. 2013. The multilateral development banks in Latin America and the Caribbean region. [Online]. Available: http://vjel.vermontlaw.edu/ files/2013/06/The-Multilateral-Development-Banks-in-Latin-America-and-theCaribbean-Region.[Accessed: 7 May 2016].

Bank for Development and Foreign Economic Affairs (VEB). 2015a. About VEB. [Online]. Available: http://www.veb.ru/en/about/today [Accessed: 4 March2016].

Bank for Development and Foreign Economic Affairs (VEB). 2015b. Developing Banking in Russia. [Online]. Available: http://veb.ru/common/upload/ pdf/277390-Vnesheconombank.pdf [Accessed: 4 March 2016].

Bank for Development and Foreign Economic Affairs (VEB). 2014. 2013 Annual Report. [Online]. Available: http://veb.ru/common/upload/files/veb/reports/ annual/VEB Annual 2013 eng.pdf [Accessed: 4 March 2016].

Biswas, R. 2015. Reshaping the financial architecture for development finance: the new development banks. LSE Global South Unit Working Paper 3. [Online]. Available: http://www.lse.ac.uk/internationalRelations/centresandunits/ globalsouth/documents/LSE-GSU-Working-Papers/working\%20papers/ LSE_Working_Paper_02_15.pdf. [Accessed: 19 September 2016].

BRICS. 2014a. Sixth BRICS Summit Fortaleza Declaration. [Online]. Available: http://brics6itamaraty.gov.br/media2/press-releases/214-sixth-brics-summitfotaleza-declaration [Accessed: 8 December 2015].

BRICS. 2014b. Agreement of the New Development Bank. [Online]. Available: http://brics6itamaraty.gov.br/agreements [Accessed: $\underline{8}$ December 2015]. 
BRICS. 2014c. Treaty for the Establishment of a BRICS Contingent Reserve Arrangement- Fortalezal. [Online]. Available: http://brics6itamaraty.gov. br/ media2/press-releases/220-treaty-for-the-establishment-of-a-brics-contingentreserve- arrangement-fortaleza- [Accessed: $\underline{8}$ December 2015].

BRICS. 2013a. The Fifth BRICS Summit, [Online]. Available: http:// www.brics5.co.za [Accessed: 4 December 2015].

BRICS. 2013b. Fifth BRICS Summit Declaration and Action Plan. [Online]. Available: http://www.brics5.co.za/fifth-brics-summit-declartion-and-action-plan [Accessed: 4 December 2015].

Cattaneo, N., Biziwick, M., and Fryer, D. 2015. The BRICS Contingent Reserve Arrangement and its Position in the Emerging Global Financial Architecture. SAIIA Policy Insights, 10: 1-7. [Online]. Available: http://www.saiia.org.za/ policy-insights/the-brics-contingent-reserve-arrangement-and-its-position-inthe-emerging-global-financial-architecture [Accessed: 12 January 2016].

Chandrasekhar, C. P. 2014. Development Finance in India. [Online]. Available: https://in.boell.org/sites/default/files/uploads/2014/03/ development_finance_in_india.pdf. [Accessed: 07 May 2016].

China Development Bank. 2015a. About CBD. [Online]. Available: http:// www.cdb.com.cn./English/Column.asp?ColumnID=99 [Accessed: 20 January 2016].

China Development Bank. 2015b. 2014 Annual Report. [Online]. Available: http:// www.cdb.com.cn/English/Column/.asp?Columid=91 [Accessed: 20 January 2016].

Corkin, L., Burke, C., and Davies, M. 2008. China's role in the development of Africa's infrastructure. Africa Studies Program, Working Paper, 04-08, Stellenbosch. [Online]. Available: http://www.sais-jhu.edu/academics/regionalstudies/Africa [Accessed: 10 September 2016]. 


\section{AFRICAN \\ EAST-ASIAN \\ AFFAIRS

Cosser, M. 2014. BRICS in South Africa and the Think Tank in BRICS. HSRC South African BRICS Think Tank Policy Insights. Pretoria.

Department of Internal Relations and Cooperation. 2014. Papers of the fifth BRICS Academic Forum, Partnership for Development, Integration and Industrialisation. Department of Internal Relations and Cooperation of South Africa.

Dixit, A. K. 2004. Lawlessness and economics: alternative models of economic governance. Princeton: Princeton University Press.

Dixon, C. 2015. The New BRICS Bank: challenging the international financial order? Global Policy Institute Policy Paper, (28):1-13. [Online]. Available: http://www.gpilondon.com/category/publications/policy-papers/ [Accessed: 20 January 2016].

Driscoll, D. D. 1996. The IMF and the World Bank - how do they differ. [Online]. Available: $\quad$ https://www.imf.org/external/pubs/ft/exrp/differ/differ.htm [Accessed: 28 May 2016].

Einchengreen, B. 2014. Will the new BRICS institutions work? World Economic Forum, Agenda, [Online]. Available: https://agenda.weforum.org/2014/08/brics -new- development-bank-contingent-reserve-agreement. [Accessed: 13 August 2015].

EurActiv. 2014. BRICS launch New Development Bank. [Online]. Available: http:// www.euroactiv.com/sections/development-policy/brics-launch-newdevelopment-bank-303506 [Accessed: 13 November 2015].

Export-Import Bank of India (EXIMINDIA). 2015a. 2014-2015 Annual Report. [Online]. Available: http://www.eximbankindia.in/sites/default/files/English\% 20Annual\%20Report_0.pdf [Accessed: 20 January 2016].

Humphrey, C. 2014. Developmental revolution or Bretton Woods revisited? The Prospects of the New Development Bank and the Asian Infrastructure Investment Bank. ODI Working Paper 418:1-42. 
Jobelius, M. 2007. New Powers for Global Change, Challenges for the International Development Cooperation: The Case of India. FES Briefing Paper 5:1-12.

Latin American and Caribbean Economic System: SELA. 2015. Analysis of the economic and financial relations between Latin America and the Caribbean and the BRICS group. Extra Regional Relations, Regional Seminar on the economic and financial relations between Latin America and the Caribbean and BRICS Group, Caracas, Venezuela, SP/SRREF-ALC-BRICS/DT N ${ }^{\circ} 2-15$.

Leahy, J. 2015. BNDES: Lender of first resort for Brazil's tycoons. The Financial Times. [Online]. Available: http://www.ft.com/cms/s/0/c510368e-968e-11e4922f-00144feabdc0.html [Accessed: 24 May 2016].

Morozkina, A. 2015. National and Multilateral DFIs in Russia and the impact of the BRICS

New Development Bank, GEGAAFRICA, BRICS Insights Paper 4. [Online]. Available: www.saiia.org.za/.../760-brics-insights-4-national-and-multilateral-Dfis-in -russia-and-the-impact-of-the-brics-new-development -bank- [Accessed: 04 January 2016].

McCutchan, A. 2010. Understanding the Inefficacy of Structural Adjustment Programs in Latin America Lund University. Master programme in Economic History (unpublished Thesis). [Online]. Available: http://lup.lub.lu.se/studentpapers/record/1641931/file/1658761.pdf. [Accessed: 28 May 2016].

National Bank for Economic and Social Development (BNDES). 2015a. O BNDES. [Online]. Available: http://www.bndes.gov.br/SiteBNDES/bndes/bndes_pt/ Institucional/ O_BNDES/A Empresa [Accessed: 22 January 2016].

National Bank for Economic and Social Development (BNDES). 2015b. Annual Report. [Online]. Available: http://www.bndes.gov.br/SiteBNDES/bndes/ bndespt/Galerias/Arquivos/ empresa/RelAnual/ra2014/RA2014ing.pdf [Accessed: 22 January 2016].

Qobo, M., and Soko, M. 2015. The Rise of Development Finance Institutions: South 


\section{AFRICAN \\ EAST-ASIAN \\ AFFAIRS

Africa, BRICS and Regional Strategy. BRICS Insights Paper 3, South African Institute of International Affairs. [Online]. Available: http://www.saiia.org.za/ news/brics-insights-papers-brics-and-development-finance-institutions [Accessed: 22 December 2015].

Reisen, H. 2013. Noch eine Entwicklungsbank: die BRICS-Bank, DIE aktuelle Kolumne 2:3-32.

Schablitzki, J. 2014. The BRICS Development Bank: A New Tool for South-South Cooperation? BRICS Policy Centre, Policy Brief 5(1): 1-12.

Sampaio, A.V. 2015. Regional Financial Institutions and the Role of the BNDES in Latin America, GEGAfrica, BRICS Insights Paper 5, South African Institute of International Affairs. [Online]. Available: http://www.saiia.org.za/news/bricsinsights-papers-brics-and-development-finance-institutions [Accessed: 12 January 2016].

Seatzu, F. 2014. The Sub-regional Development Banks and the expansion of SocioEconomic Growth in Latin America: Current Issues and Future Prospects. [Online]. Available: http://www.cedin.com.br/wp-content/uploads/2014/05/The -Subregional-Development-Banks-and-the-Expansion-of-Socio-EconomicGrowth-in-Latin-America-Current-Issues-and-Future-Prospects.pdf. [Accessed: 07 May 2016].

Singh, S., and Mukamba, C. 2015. India's Experience with Multilateral Financial Institutions: Insights for the BRICS New Development Bank. BRICS Insights Paper 1, South Africa Institute of International Affairs. [Online]. Available: http://www.saiia.org.za/news/brics-insights-papers-brics-and-developmentfinance-institutions [Accessed: 13 December 2015].

The Development Bank of Southern Africa: DBSA. 2015a. About DBSA. [Online]. Available: $\quad$ http://www.dbsa.org/EN/About-Us/Pages/About-Us.aspx [Accessed: 14 January, 2015].

The Development Bank of Southern Africa: DBSA. 2015b. 2014 Integrated Annual 
Report. [Online]. Available: http://www.dbsa.org/EN/About-Us/Publications/ eBooks/Pages/2014-Integrated-Annual -Report-.aspx [Accessed: 14 January 2016].

Zhu, J. 2015. New South-South Co-operation and the BRICS New Development Bank, BRICS Insights Paper 2. [Online]. Available: www.saiia.org.za/.../740brics-insights-1-new-south-south-co-operation- [Accessed: 23 October 2015]. 